\title{
DETERIORATION AND CONSERVATION OF AN ASSYRIAN BRONZE KNEADING BOWL
}

\author{
Gehan Adel Mahmoud ${ }^{1}$ and Abdel Rahman Elserogy ${ }^{2}$ \\ ${ }^{1}$ Faculty of Archaeology, Luxor University (Egypt) \\ gehanadel@,farch.luxor.edu.eg \\ ${ }^{2}$ Faculty of Archaeology, Fayoum University (Egypt) \\ as00@,fayoum.edu.eg
}

\begin{abstract}
An Assyrian bronze kneading bowel is preserved in the storage area of the Jordanian Heritage Museum. Its diameter is $37 \mathrm{~cm}$, and the height is $16 \mathrm{~cm}$. The bronze bowl suffered from many corrosion forms, as different corrosion layers are visible on the surface. The bronze disease appears in different parts, damaging parts of the edges of the bronze bowl, and holes in the bowl's body. Samples of corrosion layers were studied using Light Optical Microscope (LOM), Scanning Electron Microscope (SEM), X- Ray diffraction (XRD), and (EDX). Analyses indicated that atacamite and paratacamite minerals were the main components in the corrosion samples in addition to quartz and cuprite minerals. Treatment and conservation of the bronze bowl included mechanical and chemical cleaning. Localized electrochemical reduction was used to remove the bronze disease as hydrogen ions reduced these compounds and convert them into watersoluble compounds. A mixture of beeswax, dammar, and colophony resin was used to fill the holes in the bowl body and to complete the edges. Finally, the bronze bowl was isolated using benzotriazole $3 \%$.
\end{abstract}

KEYWORDS

Bronze, Kneading Bowl, Bronze Disease, Corrosion, Conservation
الملخص

يتناول هذا البحث وعاء عجن آشوري من البرونز محفوظ في مخزن متحف التراث الأردني. قطر الوعاء 37 سم ، وارتفاعه البرون 16

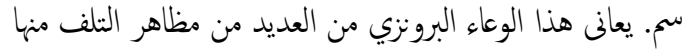

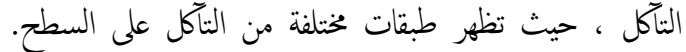

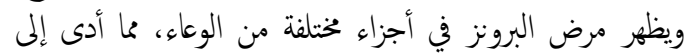

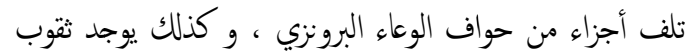

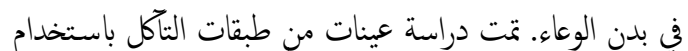

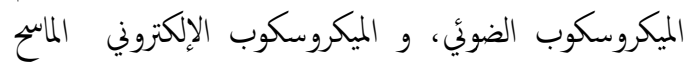

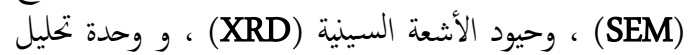

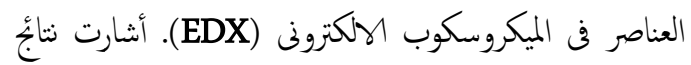

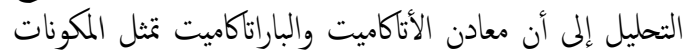

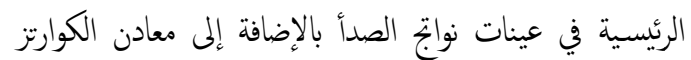

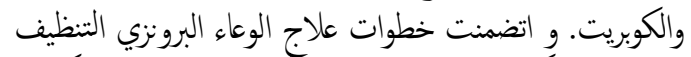
الميكانيكي والكيميائي. كذلك تم استخدام الاختزال الكهرويميائي

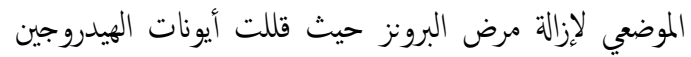

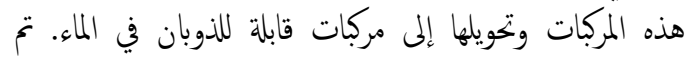

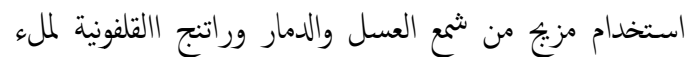

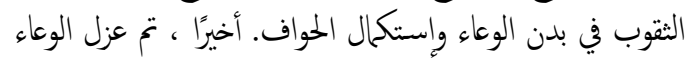

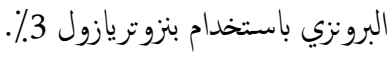
الكلمات المالة البرونز ، وعاء ججن، مرض البرونز ، صدأ، صيانة 


\section{INTRODUCTION}

Jordan has a rich heritage of artifacts made of copper and bronze alloy belonging to different civilizations, many of which are displayed in the Jordan Museum in Amman. These come from Lebanon, Syria and Jordan. ${ }^{1}$ The atomic absorption spectrometry results of copper-based objects found in Jordan show that the objects were made of different types of copper alloys that contained various amounts of zinc, tin and lead. ${ }^{2}$ The lead isotope compositions of the objects match well that of the copper ore mined from the Dolomite-Limestone-Shale unit of the Arabah copper mines. ${ }^{3}$ The Jordan Museum in Amman has an archaeological bronze kneading bowl from the Assyrian civilization, coming from Syria. Its diameter is $37 \mathrm{~cm}$, and its height is $16 \mathrm{~cm}$. The bowl was made using a cold forming method by hammering. ${ }^{4}$ Its outside surface was decorated with motifs executed by grooving or engraving with metal pens, Fig. (1). ${ }^{5}$

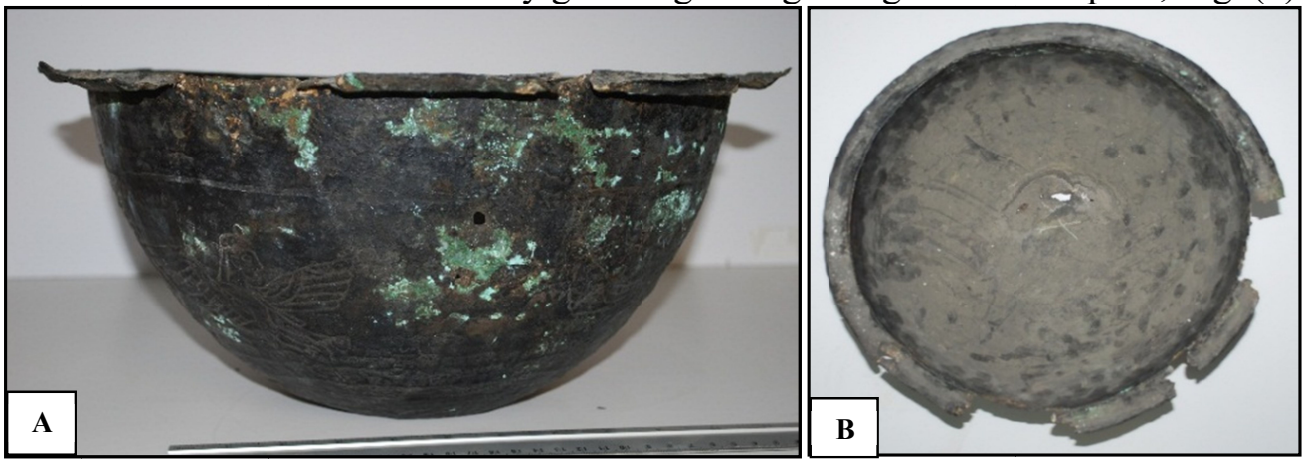

Fig. (1) A. Assyrian bronze kneading bowl with holes and corrosion layers, $B$. Missing edges of Assyrian bronze kneading bowl.

The kneading bowl was deteriorated, due to several factors. Layers of corrosion led to the erosion and then loss of parts of the bowl, especially the edges, fig. (2). The visual analysis of the corrosion layers explains this deterioration as the bronze disease ${ }^{6}$ is a form of pitting corrosion. ${ }^{7}$ It happens when chlorides come into contact with bronze or other copper-bearing alloys. In reaction, chlorine ions form copper chloride compounds, which leads to severe corrosion of the bronze artefacts. ${ }^{8}$

\footnotetext{
${ }^{1}$ El- Morr, Z.; et al ; Lefrais, Y.; Degryse, P., Copper quality and provenance in Middle Bronze Age I Byblos and Tell Arqa (Lebanon), Journal of Archaeological Science. 40: (2013), 4291- 4305.

${ }^{2}$ AL- Saad, Z., Technology and Provenance of a collection of Islamic Copper-Based objects as found in Jordan by Chemical and Lead Isotope Analysis, Archaeometry. 42(2): (2000), 385-397.

${ }^{3}$ Azaizeh, S. M., Determination of the Origin and Conservation of an Unprovenanced Metal Artifact from the Collection of the Museum of Jordanian Heritage, Master of Applied Sciences in Archaeology in the Department of Archaeology, Conservation and Management of Cultural Resources, Yarmouk University, Irbid, Jordan, (2011).

${ }^{4}$ Jones. I. W. ; Levy. T. E.; Najjar. M.; Khirbat Nuqayb al-Asaymir and Middle Islamic Metallurgy in Faynan: Surveys of Wadi al-Ghuwayb and Wadi al-Jariya in Faynan, Southern Jordan, BASOR. 368: (2012), 67-102.

5 Park JS, Joo JO, The social implications of technological variability as observed in high tin bronze objects of the Unified Silla. Korean J Met Mater 55(10) (2017):745-751

6 Chang T, Herting G, Goidanich S, Sánchez Amaya JM, Arenas MA, Le Bozec N, Jin Y, Leygraf C, OdnevallWallinder I., The role of $\mathrm{Sn}$ on the long-term atmospheric corrosion of binary $\mathrm{Cu}-\mathrm{Sn}$ bronze alloys in architecture. Corros Sci 149: (2019), Pp. 54-67.

7 Macleod, I., Bronze Disease, An Electrochemical Explanation, Institute for The Conservation of Cultural Material (INC), Volume VII (1): (1981), pp 16-26.

8 Ingo, G.M. et al, Surface studies of patinas and metallurgical features of uncommon high-tin bronze artefacts from the Italic necropolises of ancient Abruzzo (Central Italy), Applied Surface Science 470 (2019), 74-83.
}

- 251 - Deterioration and conservation of an Assyrian bronze kneading bowl 

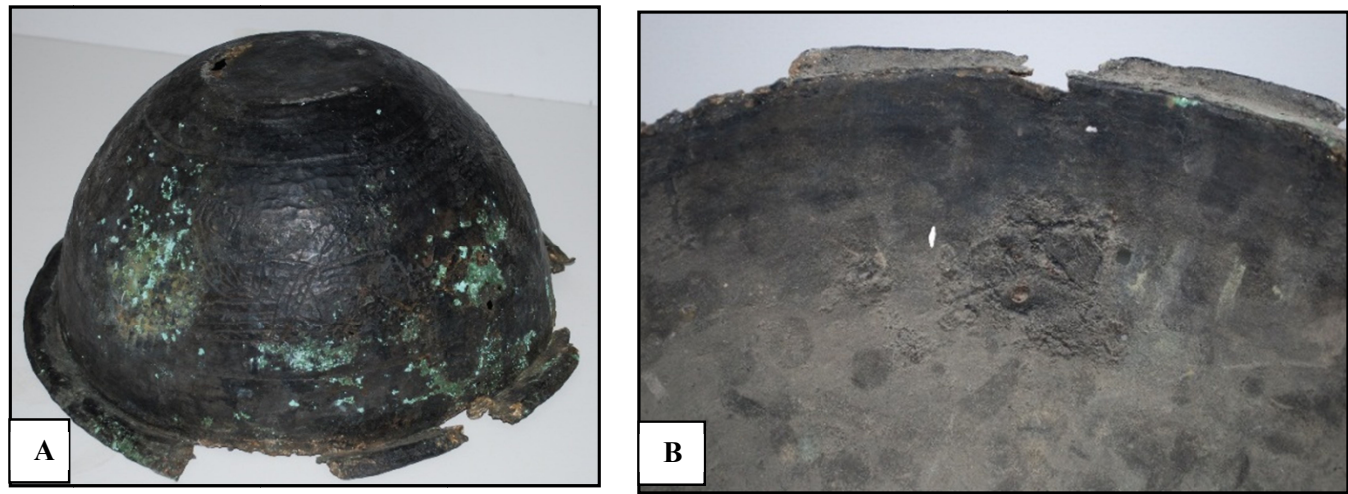

Fig. (2) A. External surface of the Assyrian bronze kneading bowl, B. Dark color of the Assyrian bronze kneading bowl interior.

Bronze disease regularly affects bronze antiquities, such as this Assyrian bronze kneading bowl. ${ }^{9}$ Leaving the bronze disease untreated may lead to further damages to the bronze object and the loss of more parts of it. This would result in a loss of human heritage. The presence of holes and gaps in separate parts of the Assyrian bronze kneading bowl is the result of deterioration, especially in the area of the edges. In addition to calcifications, deposits and dirt on the surface of the archaeological bowl. After the body was manufactured, the external motifs of the bowl were done, ${ }^{10}$ using the repousse method through the formation pens. ${ }^{11}$ Metal pens were used in slitting or engraving motifs, which were geometrical, floral or human motifs. ${ }^{12} \mathrm{~A}$ thin, smooth, and homogeneous layer covers the surface of the bowl with fine details; in this case, this layer is called noble patina. ${ }^{13}$ It is characterized by tenderness and uniformity in appearance. ${ }^{14}$ If a percentage of water vapor is available, the patina takes the form of a reddish-brown glaze layer (copper oxide). ${ }^{15}$ Spots or pits of copper chloride are the main cause of bronze disease and are visible due to their green and pale green color. ${ }^{16}$ This research aims to study the various deterioration phenomena of the Assyrian bronze kneading bowl, especially pits and clusters due to chalky green corrosion layers, the loss of some parts of the bronze bowl and corrosion in other parts, holes of all diameters occur. In addition to the identification of these issues, the treatment, restoration, and conservation processes of the Assyrian bronze kneading bowl are presented. These included mechanical and chemical cleaning and electro-chemical reduction to treat bronze disease, completing holes, and the lost

\footnotetext{
${ }^{9} 9$ Park1, J. et al, The technological and social implication of the discriminated use of tin and arsenic noted in EIA copper-based objects of Central Kazakhstan, Archaeological and Anthropological Sciences, 12, (2020), 81.

10 O'chonaghue .M ، the Ecyhopaedia of Minerals and Gemstones, ores, Geological Journal, Vol.22. Issue, 1, Orbis, London, (1985), P.35.

11 Cowell, M. The Composition of Egyptian Copper based metal- work in R.A. Dauid (edition) Science in Egyptology, Man-Work in R.A. David (edition), science in Egyptology Man-Chester university Press, Manchester, (1986), p.33.

12 Plenderlieth, The Conservation of Antiquities of Art, London, (1962), p .217 .

13 Chiavari C, et al, Composition and electrochemical properties of natural patinas of outdoor bronze monuments. Electrochim Acta 52: (2007), 760-769

14 Park1, J. et al, Op. Cit., (2020), 12: 81.

15 Ingo G.M., Surface studies of patinas and metallurgical features of uncommon high-tin bronze artefacts from the Italic necropolises of ancient Abruzzo (Central Italy), Applied Surface Science, 470, (2019), 74-83.

${ }^{16}$ Ingo, G.M. et al, Ibid, (2019), 74-83.
} 
parts. Conservation was carried out on this Assyrian bronze bowl by applying a protective anti-corrosion layer so that it stops deteriorating.

\section{MATERIALS AND METHODS}

\subsection{Sampling}

Representative samples were carefully collected from the corrosion layers and the exterior surface of the Assyrian bronze kneading bowl. These were reduced to powder for all techniques.

\subsection{Examination by USB Digital Microscope}

The surface of the bronze bowl was examined using a handheld USB digital microscope, (made in China, model PZ01, Image sensor 0.3 Megapixels, magnification factor 10 500 times, photo capture resolution $640 \times 480,320 \times 240$ ). It provided details relating to the patina features and the bronze objects.

\subsection{Scanning Electron Microscope (SEM) with Energy Dispersive X-ray analysis} (EDX)

A scanning electron microscopy equipped with energy-dispersive X-ray microanalysis (SEM-EDS) was used for investigation and for elemental analysis of the corrosion samples. SEM micrographs and EDS spectra of the selected samples were obtained by using a JSM-6380 LA instrument, equipped with a Link EDS operating up to $30 \mathrm{kV}$.

\subsection{X-ray Diffraction Analysis}

An X-ray diffractometer (XRD) was used to identify the corrosion compounds using a Philips X-ray Diffractometer type: PW1840, tube anode: $\mathrm{Cu}$, start angle ( $\left.{ }^{\circ} 2 \theta\right): 4.025$ and end angle ( $\left.{ }^{\circ} 2 \theta\right):\left({ }^{\circ} 69 \theta\right)$.

\section{RESULTS}

\subsection{USB Digital Microscope Examination}

The visual examination revealed a reddish-brown corrosion layer, in addition to green chalky one of the bronze diseases. ${ }^{17}$ The body of the bronze bowl was investigated using an optical microscope for the corrosion layers on the surface and the pitting areas. The optical microscopic examination of the corrosion layers showed that they differ in color, from green to chalky green and in thickness, from thin to thick. There are many pits in the body of the bronze bowl. It contains black layers in some parts, (Figs., 3, A, B).
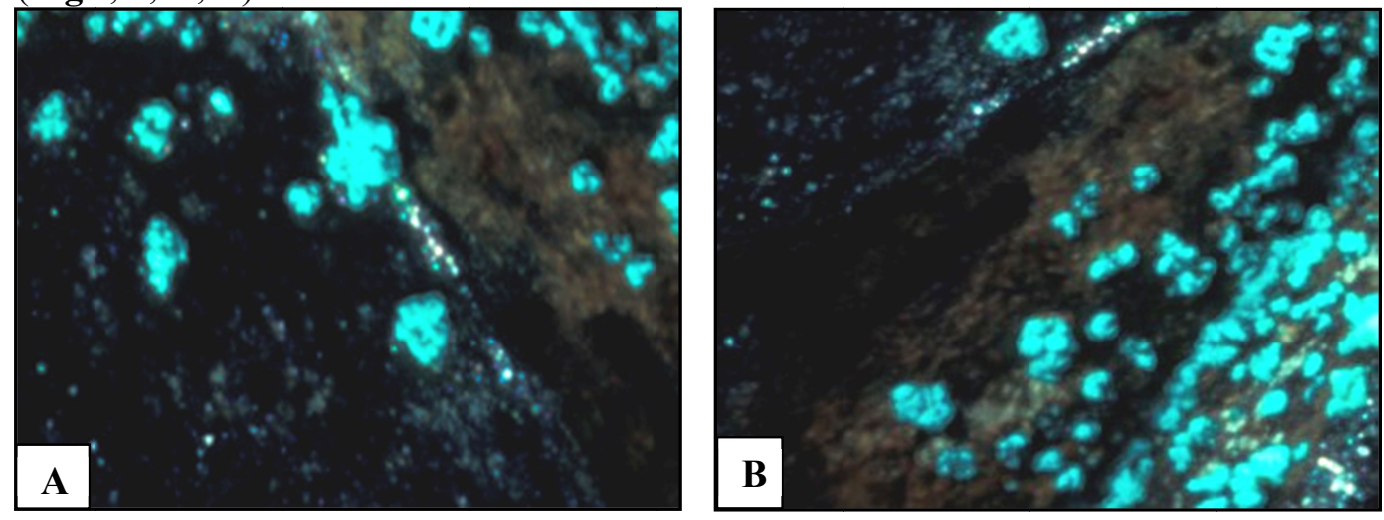

Fig. 3, Pits in the body of the bronze bowl. B. Pits of localized corrosion.

17 Schnbel ,H., Deterimental Effect of P.V.C. on Coins , ICCROM, (1984), P.60.

- 253 - Deterioration and conservation of an Assyrian bronze kneading bowl 


\subsection{Scanning Electron Microscopy (SEM) Examination}

Investigations with the scanning electron microscopic showed the morphology of the particles, deposits, eroded surfaces, mineral grains of the corrosion products, voids, micro-cracks, and pits of bronze disease, (Fig. 4, A,B and Fig. 5, A,B).
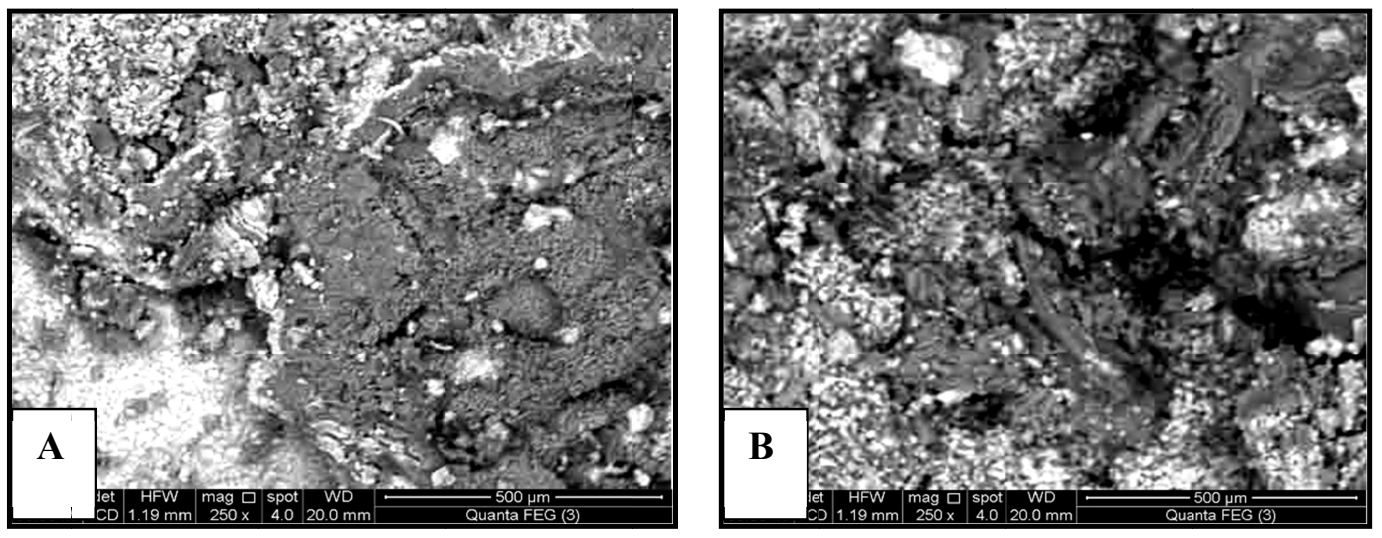

Fig. 4, A. Erosion and corrosion layers through a SEM photomicrograph, B. Voids and micro-cracks through a SEM photomicrograph of the bronze bowl.
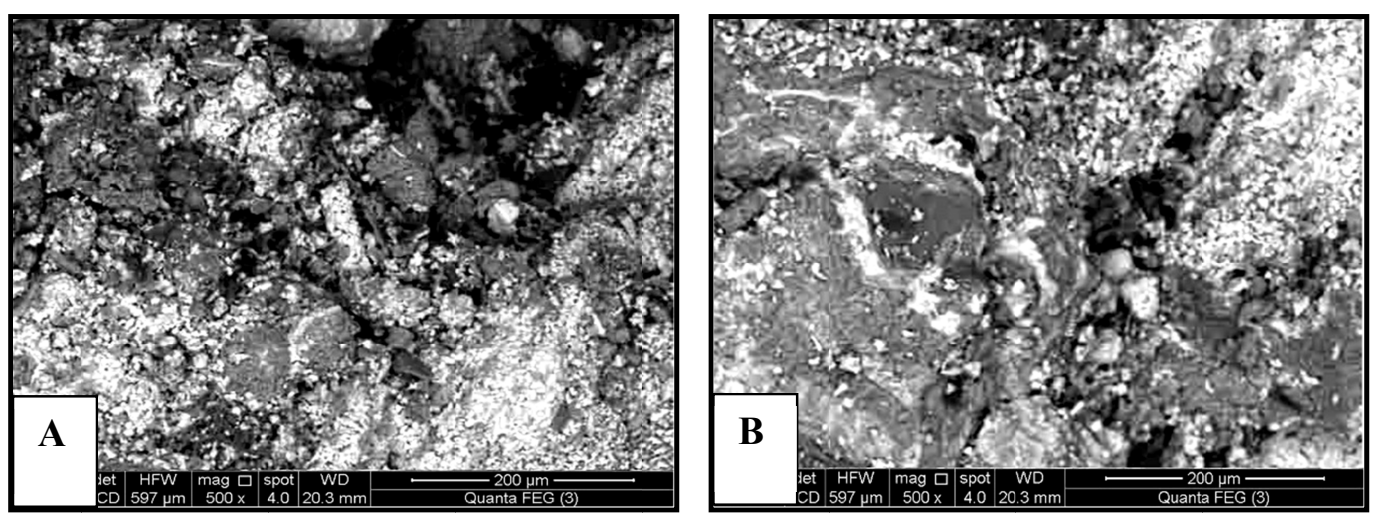

Fig. 5, A. Pits of bronze disease through a SEM photomicrograph of the bronze bowl, B. Cracks and corrosion layers seen through a SEM photomicrograph of the bronze bowl.

\subsection{Elemental Analysis of bronze objects by EDX unit}

Energy-dispersive spectrometry (EDS), which equipped with Scanning electron microscopy (SEM), was used to study the elemental composition of corroded products. The analysis of the corrosion layer on top of the metallic core revealed that contains $\mathrm{Cu}, \mathrm{Sn}, \mathrm{Ca}, \mathrm{O}$ and $\mathrm{Si}, \mathrm{Cl}, \mathrm{C}, \mathrm{Mg}$ in smaller amounts. The results indicated that $\mathrm{Cu}$ and $\mathrm{Sn}$ elements related to the bronze alloy, $\mathrm{O}, \mathrm{Cu}$, and $\mathrm{Cl}$ referred to atacamite and paratacamite minerals (Bronze Disease), and $\mathrm{Cu}$ and $\mathrm{O}$ elements with the presence of cuprite mineral, Fig. 6. 


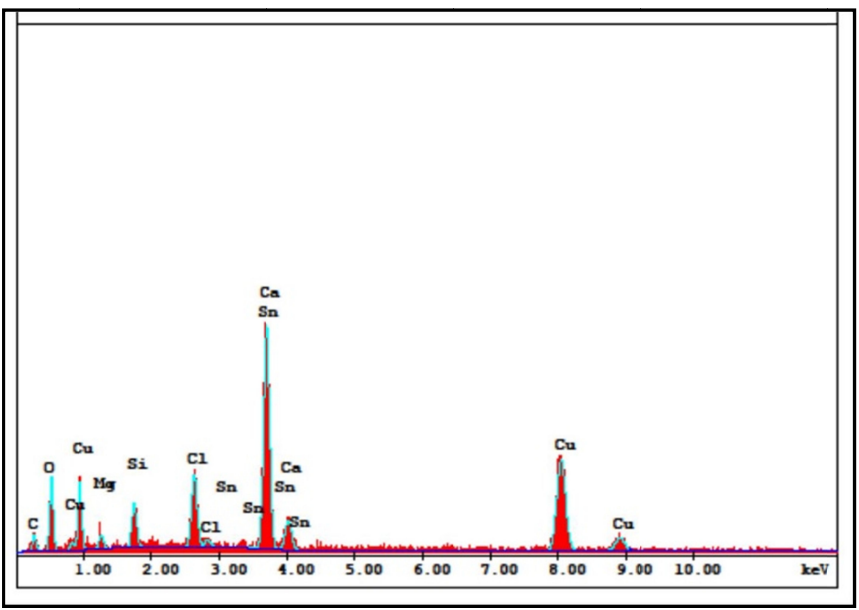

\begin{tabular}{|c|c|c|}
\hline Element & Wt \% & At \% \\
\hline $\mathrm{C} \mathrm{K}$ & 9.44 & 20.14 \\
\hline $\mathrm{O} \mathrm{K}$ & 27.38 & 43.84 \\
\hline $\mathrm{Mg} \mathrm{K}$ & 2.48 & 2.61 \\
\hline $\mathrm{Si} \mathrm{K}$ & 4.49 & 4.10 \\
\hline $\mathrm{Cl} \mathrm{K}$ & 5.98 & 4.32 \\
\hline $\mathrm{Sn} \mathrm{K}$ & 0.49 & 0.11 \\
\hline $\mathrm{Ca} \mathrm{K}$ & 20.46 & 13.08 \\
\hline $\mathrm{Cu}$ & 29.28 & 11.81 \\
\hline Total & 100.00 & 100.00 \\
\hline & & \\
\hline
\end{tabular}

Fig. (6) EDX pattern of corrosion products sample.

\subsection{X-Ray Diffraction Analysis}

The XRD spectrum of the samples consists of atacamite $\mathrm{Cu}_{2} \mathrm{Cl}(\mathrm{OH})_{3}$ [2-146] , paratacamite $\mathrm{Cu}_{2}(\mathrm{OH})_{3} \mathrm{Cl}$ [2-146], Cuprite $\left(\mathrm{Cu}_{2} \mathrm{O}\right)$ [05-0667] and quartz $\mathrm{SiO}_{2}$ [461045], as illustrated on Fig. 7. There is a reddish-brown layer on the surface of the bronze bowl due to cuprite mineral. Sampling it was difficult due to its thickness and its adherence to the surface of the bronze bowl.

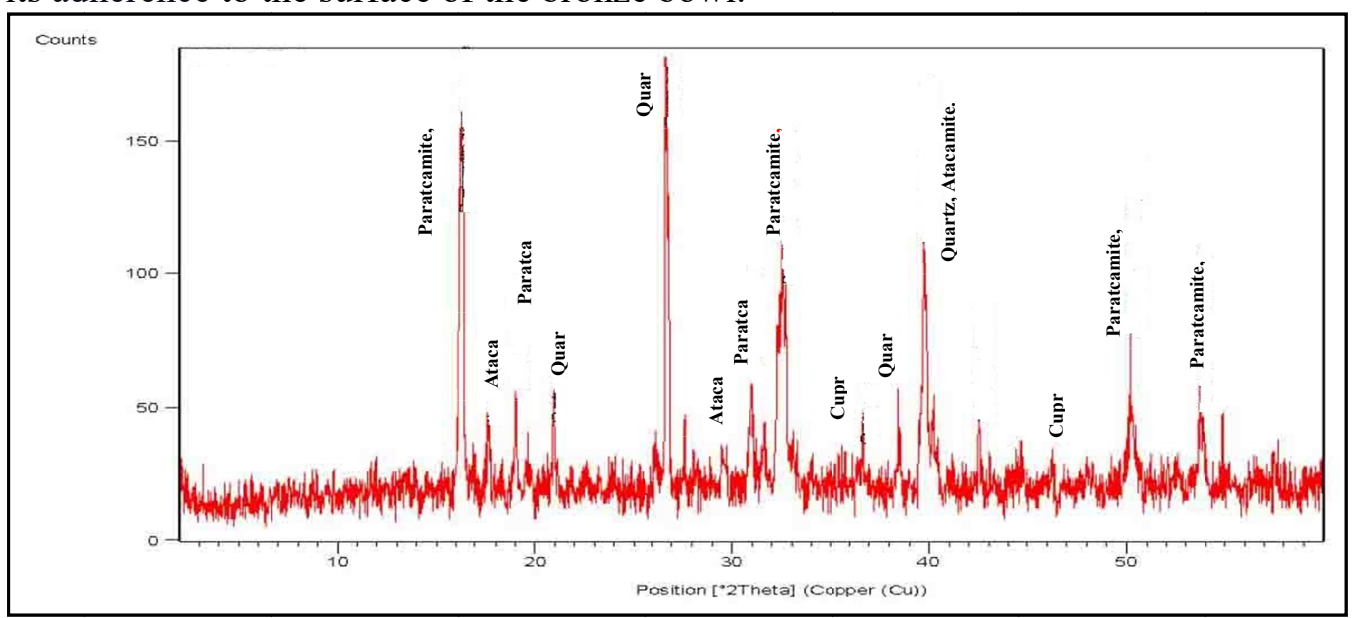

Fig. 7, XRD pattern of corrosion sample. 


\section{CONSERVATION PROCESSES}

\subsection{Cleaning}

The materials used for restoration are selected on the basis of the results of examinations and analyses. Analyses and examinations of the bronze bowl were carried out using different methods to identify the object components. ${ }^{18}$ The types of corrosion compounds are identified, and the causes of the bronze objects deterioration. The various stages to treat the bronze bowl are outlined, before the conservation processes of the deterioration phenomena.

\subsubsection{Mechanical cleaning}

The corrosion layers and some calcifications on the bronze bowl were removed (Fig. 8). Mechanical cleaning was done using fine and coarse brushes, scalpels, and spatulas to remove traces, dust, and dirt.

\subsubsection{Chemical cleaning}

Surface calcifications were removed using sodium phosphate compounds. Sodium phosphate combined with calcium or magnesium compounds in the archaeological bronze bowl. ${ }^{19}$ In the flat edges of the bronze bowl, were covered with layer of chlorides, which is insoluble in water. Removing it was done with a solution with a concentration of $5 \%$ carbonate and sodium bicarbonate (sodium sesquicarbonate). The hydroxyl ions in the basic solution chemically react with the water-insoluble copper chloride compounds. As a result, they were transformed into copper oxides compounds, which can be dissolved in water. The solution is replaced until the chloride compounds have completely disappeared. The purpose of the treatment is to remove any traces of chlorides that cause bronze disease, while preserving the patina and the decorative patterns. Holes formed by chloride ions in the archaeological bowl were removed mechanically with the use of metal needles, magnifying glass, while ensuring that the metal is not scratched. ${ }^{20}$ The chloride compounds were removed using localized electrochemical reduction by placing zinc powder in these pits or holes with formic acid in a concentration of 5\%. The released hydrogen reduces these compounds into soluble compounds (1). The object was left in this position until the corrosion layer had softened, a soft brush was then used to remove corrosion residues from the treated holes. ${ }^{21}$ After removing corrosion layers, the object was cleaned thoroughly using distilled water to clear all traces of the chemical treatment.

\subsection{Completion of Missing Parts}

The holes were supplemented with adhesives and fillers. A mixture of colophony as natural resin with beeswax and dammar, which is a reversible mixture, is regularly used to seal the holes in bronze artifacts resulting from bronze disease. ${ }^{22}$ The completion process for the lost and eroded parts of the archaeological bronze bowl was done using honey beeswax in addition to the dammar and colophony resins. Color oxides were used to homogenise the completed and the original parts. The edges were completed by making a mould with a strip of dental wax. The supplement

\footnotetext{
${ }^{18}$ Letardi P, Salvadori B, Galeotti M, Cagnini A, Porcinai S, Santagostino Barbone A, Sansonetti A., An in situ multi-analytical approach in the restoration of bronze artefacts. Microchem Journal 125: (2016), 151-158

${ }^{19}$ Petiti, C. et al, Effects of cleaning procedures on the long-term corrosion behavior of bronze artifacts of the cultural heritage in outdoor environment, Environmental Science and Pollution Research, (2020).

${ }^{20}$ Park, J., et al., The implication of diachronic changes reflected in LBA bronze assemblages of Central Kazakhstan. ArchaeolAnthropol Sci., (2020), https://doi.org/10.1007/s12520-019-00989-z.

${ }^{22}$ MichalopoulouA, V. et al, Small bronze statue from the Archaeological Museum of Thessaloniki; exploring its authenticity, STAR: Science \& Technology of Archaeological Research Journal, (2017), VOL. 3, NO. 2, 303-313.
} 
mixture consisted of beeswax in addition to the dammar and colophony resins, (Figs. $9,10)$.

\subsection{Protective Coating}

The bronze bowl was isolated using benzotriazole at a rate of $3 \%{ }^{23}$ to protect it and to prevent future deteriorations, Fig. 11. A passive film composed by an insoluble copper-BTA film was applied on the areas of active 'bronze disease' and on the cuprite $\left(\mathrm{Cu}_{2} \mathrm{O}\right)$ species that acts as a barrier protective layer, isolating the bronze artifact from oxygen and moisture. ${ }^{24}$
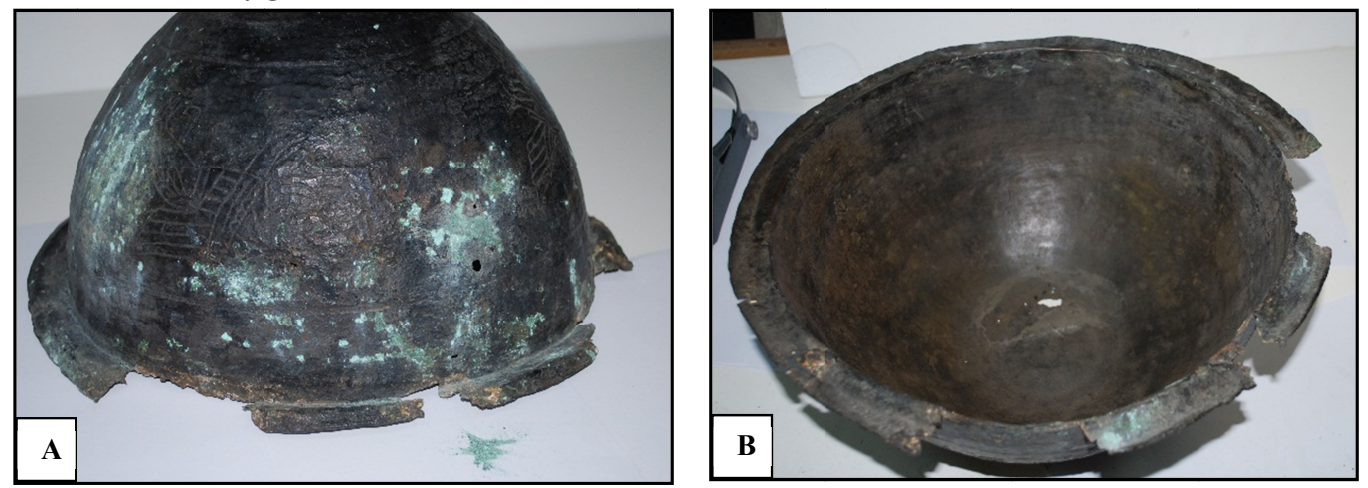

Fig. 8, Bronze bowl during (A) the mechanical cleaning (B) the chemical cleaning processes.
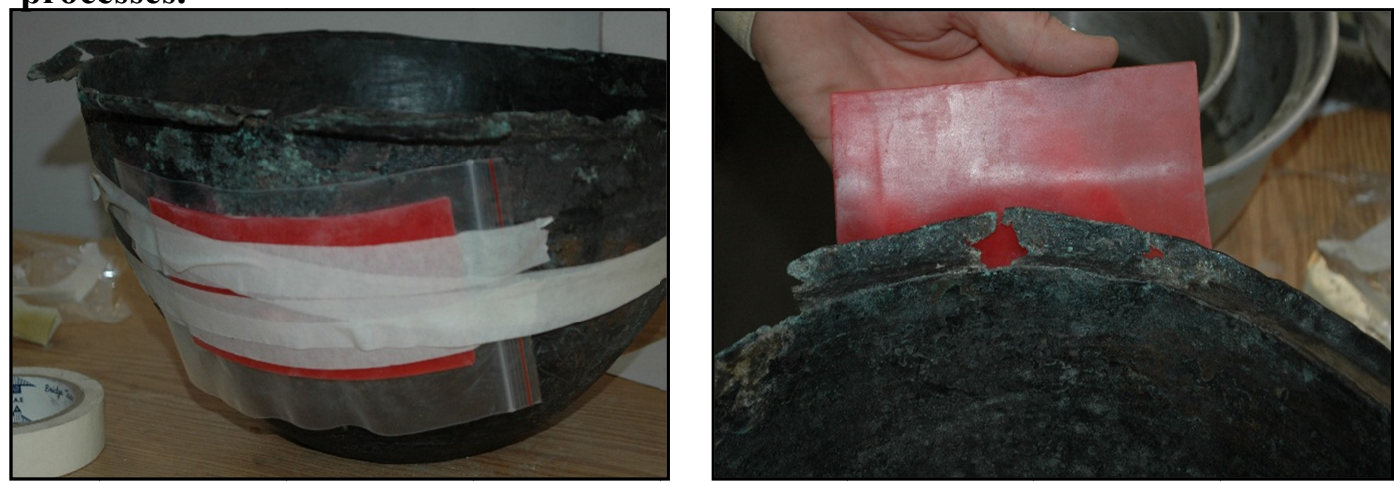

Fig. 9, Completion process of the missing parts from the bronze bowl.
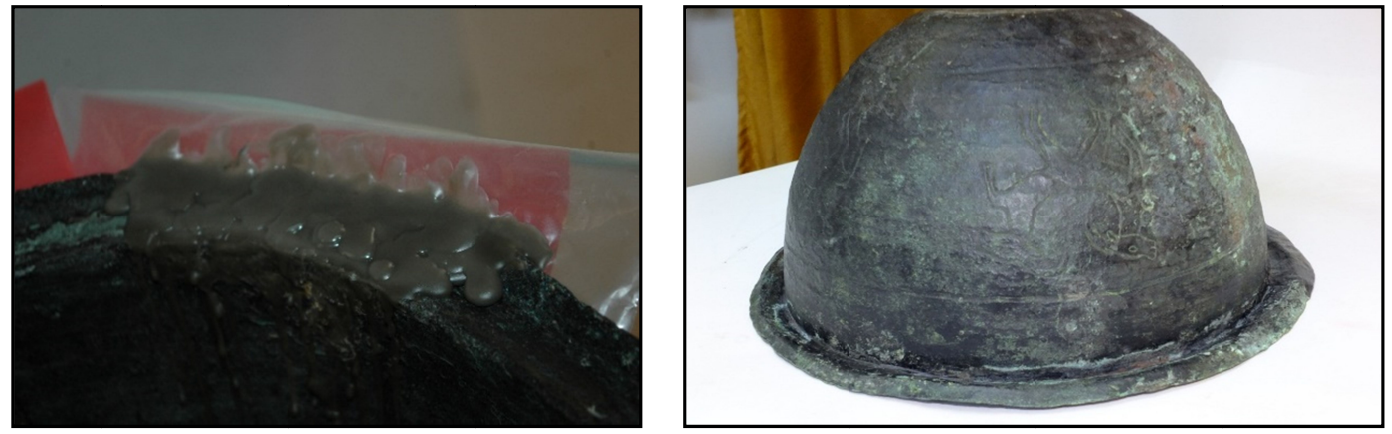

Fig. 10, Bronze bowl during the treatment and conservation processes.

\footnotetext{
${ }^{23}$ AL-Saad, Z. Anew Method for the Stabilization of Archaeological Copper- Based Artifacts, Abhath Al- Yarmouk Journal, Yarmouk University no, 5(2): (1996), 81-92.

24Mezzi, A., et al, Investigation of the benzotriazole inhibition mechanism of bronze disease, Surf. Interface Anal.2012,44, 968-971
}

- 257 - Deterioration and conservation of an Assyrian bronze kneading bowl 

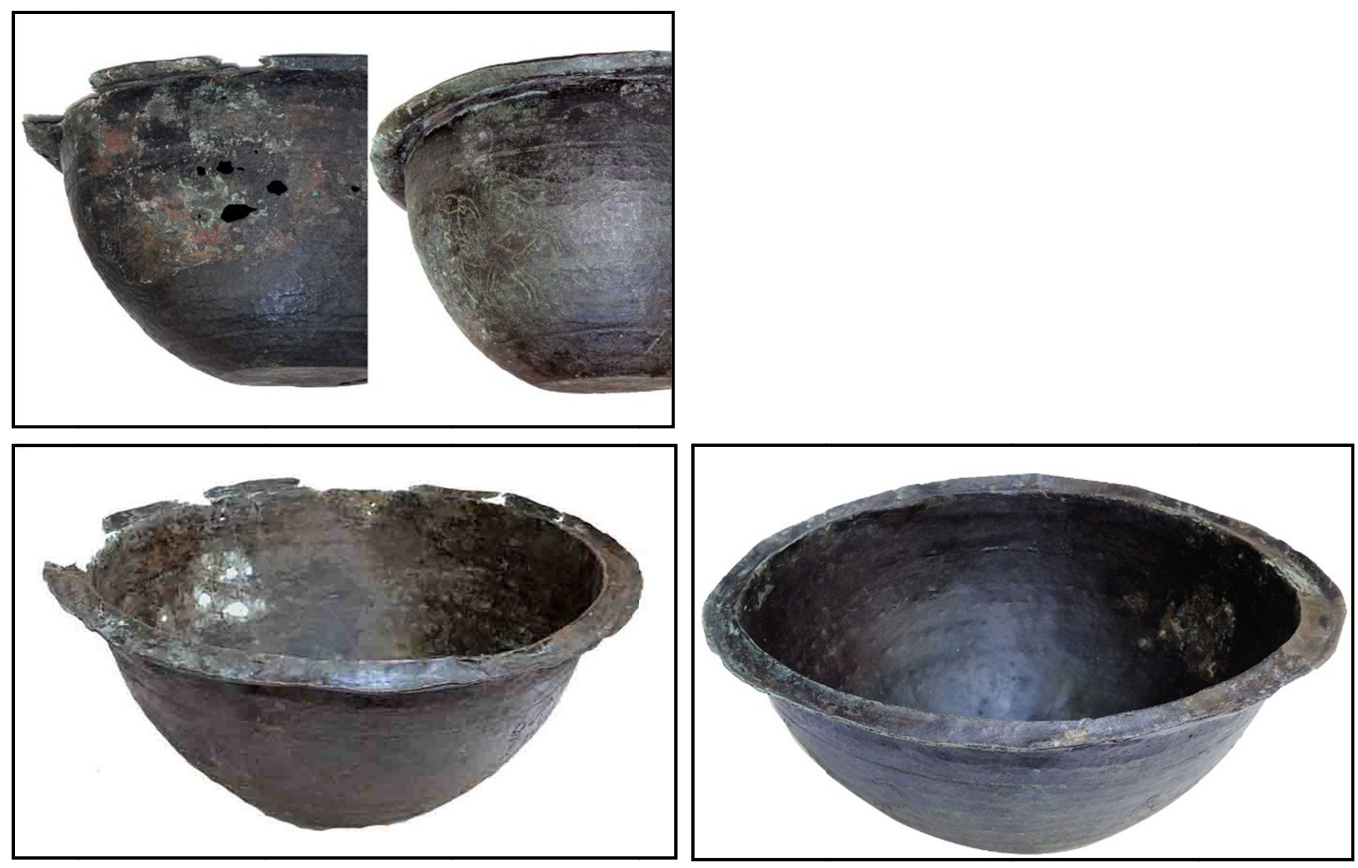

Fig. 11, Bronze bowl before and after conservation.

\section{DISCUSSION}

Examination using light optical microscopy (LOM) of the Assyrian bronze bowl surface shows corrosion layers which appeared in reddish-brown and chalky green colors. The reddish-brown corrosion layers are due to cuprite mineral while the chalky green corrosion are due to the bronze disease. ${ }^{25}$ Examinations indicated that the bronze bowl contains black layers in some parts, which may have been caused by putting it on the fire while cooking food. Examination by scanning electron microscope [SEM] shows the deteriorated state of the archaeological bowl. SEM examination was also used to determine the different corrosion layers on the surface, voids, holes, and cracks, to identify the nature of mineral grains and, the extent of correlation of the metal grains and to examine the corrosion on the surface. ${ }^{26}$ The analysis aims to determine the mineral composition of the corrosion compounds to find appropriate treatment and maintenance methods for the Assyrian bronze bowl condition. The mineral composition of corrosion samples was determined through $\mathrm{X}$ ray. X-ray diffraction analysis of the corrosion products revealed the presence of different minerals, including atacamite, paratacamite, and cuprite. Examination with a scanning electron microscope revealed eroded parts, pits, and cavities. This corroborates the results of the X-ray diffraction analysis, which proved the presence of atacamite and paratacamite minerals and the cause of bronze disease, which takes the form of localized corrosion in the form of pits and cavities. These were immediately visible with the scanning electron microscope and the optical

\footnotetext{
${ }^{25}$ Odnevall Wallinder I, Zhang X, Goidanich S, Le Bozec N, Herting G, Leygraf C., Corrosion and runoff rates of $\mathrm{Cu}$ and three Cualloys in marine environments with increasing chloride deposition rate. Sci Total Environ 472: (2014), 681-694.

${ }^{26}$ Pan C, Lv W, Wang Z, SuW, Wang C, Liu S Atmospheric corrosion of copper exposed in a simulated coastal-industrial atmosphere. J Mater Sci Technol 33(6): (2016), 587-595.
} 
microscope. The availability of chlorine ion causes the formation of spots of different shades of green, which is called bronze disease. ${ }^{27,28}$ The bronze disease appears either solely on the surface or in the depth of the bowl, as seen through radiation consuming the metal. ${ }^{29}$ It is likely that "pitting corrosion" results from the contamination of the medium surrounding the chloride as an air pollutant found in the invading medium surrounding the bowl, ${ }^{30}$ where the metal turns into copper chloride. In the case of moisture in the medium surrounding the bronze bowl, bronze converts to a copper-base chloride. ${ }^{31}$ These compounds include atacamite and paratacamite minerals. Examinations indicated that the holes and voids in separate parts of the surface of the archaeological bronze bowl emerged as a result of using high temperatures and the presence of the bronze disease, which consumes the inner metal and leads to the occurrence of these holes and voids. ${ }^{32}$ Corrosion layers of bronze disease weakens the bronze bowl in different regions, especially in the flat part of the bowl nozzle (the flat edges of the bowl), which led to the loss of parts of the bowl edges. On the other hand, it is possible that the missing parts of the bowl were lost because of the use process during kneading operations, which is the purpose of making the bowl or while holding the bowl when it was full. Copper oxides, for example, cuprite, were developed on the bronze object's surfaces due essentially to exposure to air. ${ }^{33}$ The presence of basic copper chlorides such as atacamite and paratacamite minerals are related to the presence of the dangerous chlorine anion. Atacamite usually exists under alkaline conditions. In the case of existence, a sodium carbonate and water, atacamite, may be produced. The first layer of cuprite mineral forms as a sealing layer and has protective properties as a noble patina. Nevertheless, the increase in temperature and in oxygen may break this layer. The dark green crystalline atacamite is altered to a paler green powdery compound of paratacamite. ${ }^{34}$

\section{CONCLUSION}

The study indicates that the bronze disease caused severe deterioration to this bronze object, as evidenced by bowl's condition. It showed erosion, the loss of multiple parts of the nozzle and the spread of holes of various diameters throughout the body of the bowl. Analyses showed the presence of atacamite and paratacamite minerals, which cause bronze disease. Treatment and conservation of the Assyrian bronze bowl

\footnotetext{
${ }^{27}$ Scott DA, Bronze disease: a review of some chemical problems and the role of relative humidity. J Am Inst Conserv. 29: (1990), 193-206.

${ }^{28}$ Sik Park, J., The technological and social implication of the discriminated use of tin and arsenic noted in EIA copper-based objects of Central Kazakhstan, Archaeological and Anthropological Sciences, (2020), 12: 81

${ }^{29}$ Macleod, I. Bronze Disease : An Electrochemical Explanation, Institute for the Conservation of Cultural Material (INC), Volume VII (1), (1981), pp 16-26

${ }^{30}$ Petiti, C. et al, Effects of cleaning procedures on the long-term corrosion behavior of bronze artifacts of the cultural heritage in outdoor environment, Environmental Science and Pollution Research, (2020).

${ }^{31}$ Ingo G.M., Surface studies of patinas and metallurgical features of uncommon high-tin bronze artefacts from the Italic necropolises of ancient Abruzzo (Central Italy), Applied Surface Science, 470, (2019), 74-83.

${ }^{32}$ Park, J., et al, The implication of diachronic changes reflected in LBA bronze assemblages of Central Kazakhstan. ArchaeolAnthropol Sci. (2020), https://doi.org/10.1007/s12520-019-00989-z

${ }^{33}$ Park, J. et al, the technological and social implication of the discriminated use of tin and arsenic noted in EIA copper-based objects of Central Kazakhstan, Archaeological and Anthropological Sciences, (2020), 12: 81.

${ }^{34}$ Macleod, I. Bronze Disease: An Electrochemical Explanation, Institute for the Conservation of Cultural Material (INC), Volume VII (1), (1981), pp 16-26
}

- 259 - Deterioration and conservation of an Assyrian bronze kneading bowl 
include a mechanical cleaning procedure and chemical cleaning using a localized electrochemical reduction method by placing zinc powder and formic acid at a concentration of $5 \%$ in pits infected with the bronze disease. For the flat areas in the bowl on which there is a layer of chlorides, a solution of sodium carbonate and sodium bicarbonate is used in this method (sodium sesquicarbonate). As for the calcifications on the surface of the bronze bowl, a sodium phosphate compound was used to remove these calcifications. The missing edges were supplemented by making a mould using dental wax strips, and the material consists of beeswax, dammar and colophony resins. Finally, the bronze bowl was isolated using benzotriazole $3 \%$ to protect it from further corrosion and deterioration. Research in the use of nanomaterials to fill the pits caused by the bronze disease in bronze artifacts and protective coatings made with green materials is suggested.

\section{ACKNOWLEDGMENTS}

I would like to thank the administration of the Jordanian Heritage Museum for giving the researchers a chance to study the case of this Assyrian bronze kneading bowl and carry out treatment and conservation processes on it. 


\section{REFERENCES}

1- AL-Saad, Z. A new Method for the Stabilization of Archaeological Copper- Based Artifacts, Abhath Al- Yarmouk Journal, Yarmouk University, No, 5(2): (1996), 81-92.

2- AL- Saad, Z. Technology and Provenance of a collection of Islamic Copper-Based objects as found in Jordan by Chemical and Lead Isotope Analysis, Archaeometry. 42(2): (2000), 385-397.

3- Azaizeh, S.A., Determination of the Origin and Conservation of an Unprovenanced Metal Artifact from the Collection of the Museum of Jordanian Heritage, Master of Applied Sciences in Archaeology in the Department of Archaeology, Conservation and Management of Cultural Resources, Yarmouk University, Irbid, Jordan, (2011).

4- Bertholon, (R.), Archaeological Metal Artefacts and Conservation Issues: Longterm Corrosion Studies, In Corrosion of Metallic Heritage Artefacts: Investigation, Conservation and Prediction for Long-Term Behaviour, European Federation of Corrosion Publication 48, Cambridge: Woodhead Publishing, (2007).

5- Chang (T.), et al., The role of Sn on the long-term atmospheric corrosion of binary $\mathrm{Cu}-\mathrm{Sn}$ bronze alloys in architecture. Corros Sci 149: (2019): 54-67.

6- Cowell, (M.), The Composition of Egyptian Copper based metal- work in R.A. Dauid (edition) Science in Egyptology, Man-Work in R.A. David (edition), science in Egyptology Man-Chester university Press, Manchester, (1986): 33.

7- Chiavari, (C.), Rahmouni K, Takenouti H, Joiret S, Vermaut P, Robbiola L Composition and electrochemical properties of natural patinas of outdoor bronze monuments. Electrochim Acta 52, (2007): 760-769.

8- El- Morr, Z., et al, Copper quality and provenance in Middle Bronze Age I Byblos and Tell Arqa (Lebanon), Journal of Archaeological Science. 40: (2013), 42914305.

9- Ingo (G.M.), Surface studies of patinas and metallurgical features of uncommon high-tin bronze artefacts from the Italic necropolises of ancient Abruzzo (Central Italy), Applied Surface Science, 470, (2019): 74-83.

10- Jones. I. W.; Levy. T. E.; Najjar. M.; Khirbat Nuqayb al-Asaymir and Middle Islamic Metallurgy in Faynan: Surveys of Wadi al-Ghuwayb and Wadi al-Jariya in Faynan, Southern Jordan, BASOR. 368: (2012), 67-102.

11- Letardi (P.), et al, An in situ multi-analytical approach in the restoration of bronze artefacts. Microchem J. 125: (2016): 151-158

12- $\quad$ Macleod, (I.), Bronze Disease: An Electrochemical Explanation, Institute for the Conservation of Cultural Material (INC), Volume VII (1), (1981): 16-26.

13- Mezzi, A., et al, Investigation of the benzotriazole inhibition mechanism of bronze disease, Surf. Interface Anal.2012,44, 968-971

14- Michalopoulou, A. V. et al, small bronze statue from the Archaeological Museum of Thessaloniki; exploring its authenticity, STAR: Science \& Technology of Archaeological Research Journal, VOL. 3, NO. 2, (2017), 303-313.

15- Oudbashi, (O. A.), Investigation on corrosion stratigraphy and morphology in some Iron Age bronze alloys vessels by OM, XRD and SEM-EDS methods, Applied Physics A, (2016): 122 - 262.

16- Oudbashi, (O.), From Excavation to Preservation: Preventive Conservation Approaches in Archaeological Bronze Collections, Wallon, (2015): 29-36.

- 261 - Deterioration and conservation of an Assyrian bronze kneading bowl 
17- O'chonaghue, (M), The Ecyhopaedia of Minerals and Gemstones, ores, London, (1985): 35.

18- Odnevall (W.) Corrosion and runoff rates of $\mathrm{Cu}$ and three Cualloys in marine environments with increasing chloride deposition rate. Sci Total Environ 472, (2014): 681-694

19- Papapelekanos, (A.), The Critical RH for the Appearance of "Bronze Disease" in Chloride Contaminated Copper and Copper Alloy Artefacts, E-Conservation Magazine 13, (2010): 43-52.

20- Plenderlieth, The Conservation of Antiquities of Art, London, (1962): 217.

21- Pan (C.), et al., Atmospheric corrosion of copper exposed in a simulated coastal-industrial atmosphere. J Mater Sci Technol 33(6): (2016): 587-595.

22- Petiti, (C.) et al, Effects of cleaning procedures on the long-term corrosion behavior of bronze artifacts of the cultural heritage in outdoor environment, Environmental Science and Pollution Research, (2020).

23- Park, J., et al., The social implications of technological variability as observed in high tin bronze objects of the Unified Silla. Korean J Met Mater 55(10) (2017): 745-751.

24- Park, J. et al, the technological and social implication of the discriminated use of tin and arsenic noted in EIA copper-based objects of Central Kazakhstan, Archaeological and Anthropological Sciences (2020), 12: 81.

25- Robbiola, (L.) et al., Morphology and Mechanisms of Formation of Natural Patinas on Archaeological Cu-Sn Alloys. Corrosion Science 40 (12), (1998): 2083-2111.

26- Scott, (D. A.), Copper and bronze art: corrosion, colorants, conservation, Getty Conservation Institute, Los Angeles, CA. (2002).

27- Schnbel,(H.), Deterimental Effect of P.V.C. on Coins, ICCROM, (1984): 60.

28- Scott (D.A.), Bronze disease: a review of some chemical problems and the role of relative humidity. J Am Inst Conserv. 29, (1990): 193-206

29- $\quad$ Sik (P. J.), The technological and social implication of the discriminated use of tin and arsenic noted in EIA copper-based objects of Central Kazakhstan, Archaeological and Anthropological Sciences, (2020), 12: 81.

30- Uminski, (M.) et al, The Removal of Chloride Ions from Artificially Corroded Bronze Plates, [IN:] Studies in Conservation, 40, (1995): 247-278.

31- Walker, (R.), Benzotriazole as a Corrosion Inhibitor for Copper, Anticorrosion Methods, and materials, 17, (1970):9-15. 